\title{
A origem do homem americano vista a partir da América do Sul: uma ou duas migraçóes?
}

\author{
Walter A. Neves \& Danilo V. Bernardo \\ Laboratório de Estudos Evolutivos Humanos, \\ Departamento de Genética e Biologia Evolutiva - IB/USP \\ Maria Mercedes M. Okumura \\ Leverhulme Centre for Human Evolutionary Studies \\ - University of Cambridge
}

RESUMO: Até meados da década de 1990, predominava na literatura especializada que o Novo Mundo teria sido colonizado por três levas distintas, todas com origem no nordeste asiático. Na segunda metade da década, dois modelos alternativos começaram a desfrutar de grande popularidade entre a comunidade acadêmica internacional. O primeiro deles, denominado "Modelo dos Dois Componentes Biológicos Principais", baseado na variabilidade craniométrica de populações nativas americanas extintas, sugere que a América teria sido colonizada por pelo menos duas populaçôes morfologicamente distintas vindas do nordeste asiático. O segundo, gerado por pesquisas sobre a variabilidade do DNA mitocondrial e do cromossomo Y de populações indígenas atuais, defende que o continente americano teria sido colonizado por apenas uma migração, também de origem asiática. Alguns especialistas acreditam que a compatibilização desses dois modelos é simples: as duas morfologias que se sucederam no tempo no Novo Mundo são resultado de um processo microevolutivo local, independente daquele que ocorreu, em paralelo, na Ásia. Uma outra maneira de compatibilizar os dois cenários é assumir que morfologia craniana e linhagens de DNA são entidades evolutivamente independentes, com histórias, modos, tempos e tendên- 
Walter A. Neves; Danilo V. Bernardo \& Maria M. M. Okumura

cias próprias. Este trabalho apresenta novas evidências de que dois padrões morfológicos cranianos de fato se sucederam no Novo Mundo. Um relacionado às populaçôes mais antigas (paleoíndias) e um relacionado a populaçôes arcaicas e agrocerâmicas. Esses resultados são analisados à luz da discussão acima caracterizada.

PALAVRAS-CHAVE: Modelo das Três Migraçôes, Modelo dos Dois Componentes Biológicos Principais, variabilidade do DNA, morfologia craniana, primeiros americanos.

\section{Introdução}

Até meados dos anos 1990, predominava na literatura a idéia de que a ocupação da América pelo Homo sapiens teria se dado por três levas distintas. Uma primeira, conhecida como Ameríndia, teria dado origem à esmagadora maioria dos índios das três Américas; uma segunda, aos $\mathrm{Na}$-Dene da costa pacífica do Canadá e dos Estados Unidos; e uma terceira, responsável pelos atuais esquimós e aleútes. Denominado "Modelo das Três Migraçôes”, foi sugerido no início dos anos 1980 por Cristy Turner II, Stephen Zegura e Joseph Greenberg, baseado em três pilares: a diversidade dentária, lingüística e genética das populações nativas americanas. Quando da publicação original do modelo (Greenberg et al., 1986), os estudos sobre variabilidade genética baseavam-se em produtos gênicos, como as proteínas séricas, por exemplo, e não na diversidade do DNA propriamente dito.

A partir de meados dos anos 1990, mas principalmente a partir do final da década, dois outros modelos passaram a desfrutar de grande interesse entre a comunidade especializada, sobretudo porque questionavam seriamente o modelo tripartite. $\mathrm{O}$ primeiro deles, originalmente batizado por Neves e Pucciarelli (1989, 1990, 1991) como "Modelo das Quatro Migrações", foi mais tarde renomeado "Modelo dos Dois Com- 
ponentes Biológicos Principais" por duas razões: a dificuldade de se estabelecer, de fato, o número real de migrações que ocorreu no processo de colonização da América e o progresso das informações advindas da Biologia Molecular, baseadas agora no estudo dos polimorfismos da própria fita do DNA recombinante.

É improvável que o número de migrações que deu origem aos nativos americanos possa um dia ser conhecido. Se uma mesma população asiática contribuiu diversas vezes nesse processo com um número significativo de indivíduos, torna-se bem pouco provável que se consiga distinguir esse cenário de um que assume ter havido apenas uma migração desses asiáticos para o Novo Mundo (Goebel et al., 2008). Portanto, é possível conhecer quantas populações asiáticas diferenciadas contribuíram para a formação dos povos nativos americanos, mas não em quantas migrações essas contribuições ocorreram. Dito de uma outra forma, uma mesma população biológica siberiana pode ter contribuído para a ocupação da América por meio de várias migrações, ou melhor, por meio de vários eventos de expansão na direção leste.

Conforme mencionado anteriormente, informações geradas pela Biologia Molecular também tiveram grande peso na renomeação do modelo originalmente defendido por Neves e Pucciarelli (1989, 1990, 1991). Durante os anos 1990 o uso da variabilidade do DNA mitocondrial e do cromossomo $Y$ apontou para várias direções, tendo sido sugeridos modelos de uma a quatro migrações - para uma revisão, ver Schurr (2004). Mais para o final da década e especialmente a partir dos anos 2000, o DNA de cromossomos autossômicos passou também a integrar o estudo da variabilidade genética das populações nativas americanas.

Dispondo agora de vários tipos de marcadores moleculares, os geneticistas começaram a gerar informaçôes mais convergentes, informaçôes essas que apontavam e continuam apontando, apesar de algumas dissidências, para um cenário de apenas uma única migração (Goebel 
Walter A. Neves; Danilo V. Bernardo \& Maria M. M. OKumura

et al., 2008). Em outras palavras, enterrou-se oficialmente o "Modelo das Três Migrações" e nesse novo contexto não havia mais sentido manter o nome original do modelo proposto por Neves e Pucciarelli, tendo em vista que ele foi adotado partindo-se do pressuposto que o modelo tripartite estava pelo menos parcialmente correto.

Diferentemente dos estudos sobre polimorfismos de DNA, o "Modelo dos Dois Componentes Biológicos Principais” emergiu da análise da variabilidade morfocraniana de populaçôes nativas extintas (a diversidade do DNA fóssil obtido de esqueletos humanos pré-históricos americanos ainda é pouco conhecida). O pilar do modelo é que, do ponto de vista da morfologia craniana, os grupos nativos americanos parecem se resolver em dois grandes padrões. Um primeiro, caracterizado por neurocrânios longos e estreitos, faces baixas e prognatas, com órbitas e nariz também baixos, e um segundo, por neurocrânios curtos e largos, faces altas e ortognatas, com órbitas e nariz também altos (Neves \& Hubbe, 2005).

Esses dois padrões sucederam-se à primeira morfologia, hoje conhecida como Paleoamericana, caracterizando os primeiros imigrantes; e à segunda morfologia, denominada ora como Mongolóide, ora como Ameríndia, caracterizando as populações nativas mais tardias, recentes e atuais. Outra premissa do modelo é que esses dois padrôes se diferenciaram no Velho Mundo, tendo chegado às Américas já como tais (assunto desenvolvido com mais detalhes em Discussão e Conclusões). Do ponto de vista arqueológico, pode-se dizer que, grosso modo, a primeira morfologia predomina no período Paleoíndio (entre 12 e 8 mil anos atrás), enquanto a segunda predomina a partir do período Arcaico (mais recente que 8 mil anos).

Vale dizer que a morfologia paleoamericana é muito similar àquela que caracterizou os primeiros Homo sapiens, que da África se dispersaram por todo o planeta, a partir de 50 mil anos, antes que o processo de 
Revista de Antropologia, São Paulo, USP, 2007, v. 50 No 1.

raciação tivesse ocorrido (Lahr, 1995, 1996). Por isso é às vezes denominada "morfologia generalizada" ou "morfologia primitiva", para usar um termo da cladística (Henning, 1965). Já a segunda leva que entrou no continente em tempos mais recentes corresponderia a populaçōes já racializadas no nordeste asiático, cuja morfologia craniana é denominada às vezes "morfologia especializada" ou "morfologia derivada".

A disponibilidade de esqueletos de origem arqueológica com mais de 8 mil anos na América é muito limitada (Jantz \& Owsley, 2001; Powell, 2005). No norte, pode-se contar com os dedos das mãos os espécimes disponíveis. O quadro na América do Sul é mais generoso, sobretudo em duas regiões, Lagoa Santa e Savana de Bogotá. Entretanto, amostras de esqueletos do período Arcaico são raras no sul. Uma das exceçôes neste último caso é representada pelos sambaquis da costa brasileira, de onde milhares de esqueletos humanos já foram exumados. Por outro lado, a maioria dos crânios exumados de sambaquis apresenta-se muito fragmentada em decorrência do peso exercido pelas camadas conchíferas, impedindo a caracterização craniométrica.

Neste trabalho investigamos o cenário preconizado pelo "Modelo dos Dois Componentes Biológicos Principais", usando para tanto três amostras esqueletais numericamente expressivas, cronologicamente distintas, da América do Sul. Uma do período Paleoíndio, uma representando o período Arcaico e uma última, o período agrocerâmico tardio - este último caracterizado pela agricultura intensiva, com terraceamento e irrigação. Se o modelo testado estiver correto, a amostra paleoíndia deve se diferenciar significativamente das demais, ao passo que a amostra arcaica e a amostra agrocerâmica deverão guardar grande identidade morfológica entre si, apesar da enorme distância geográfica que as separa. 
Walter A. Neves; Danilo V. Bernardo \& Maria M. M. Okumura

\section{Material e métodos}

Três amostras numericamente expressivas foram utilizadas neste trabalho, totalizando 224 crânios. A primeira amostra, composta de 32 espécimes, denominada Lagoa Santa, corresponde ao período Paleoíndio; esses indivíduos distribuem-se temporalmente entre 11 e 8 mil anos antes do presente. A segunda, composta de 82 espécimes, denominada Sambaqui, corresponde ao período Arcaico; esses indivíduos estão datados do final do primeiro milênio da era cristã. Ao passo que a terceira, composta de 110 espécimes, denominada Peru, corresponde ao período agrocerâmico intensivo andino e data, grosso modo, dos últimos séculos antes do contato europeu. A tabela 1 fornece esses elementos de maneira sintetizada.

Como podem ser observados na tabela 1 , os sambaquis brasileiros estão representados pelos sítios Tapera e Base Aérea, da Ilha de Santa Catarina, embora os grupos que ali viveram não construíssem mais sambaquis e já fabricassem cerâmica (Schmitz, 1959, 1996; Neves, 1988; Okumura, 2007). Não há, entretanto, qualquer indicativo de que praticavam o cultivo de vegetais sistematicamente. Trabalhos anteriores (Neves, 1988; Okumura, 2007) demonstraram que, do ponto de vista da anatomia e da morfologia craniana, estas duas amostras apresentam grande identidade morfológica com os sambaquis clássicos (datados entre aproximadamente 6 e 1 mil anos antes do presente), o que justifica, portanto, sua inclusão neste estudo representando o período Arcaico. Além disso, Tapera e Base Aérea apresentam um grande número de crânios bem preservados, minimizando a substituição de valores eventualmente faltantes (missing values).

A caracterização da morfologia craniana das três séries ou amostras foi realizada a partir de 20 variáveis craniométricas no caso dos homens e 22 no caso das mulheres; variáveis estas descritas e adotadas por W. 
W. Howells em seus trabalhos seminais sobre a diversidade morfocraniana no planeta $(1973,1989,1999)$. A tabela 2 apresenta essas variáveis fornecendo também as siglas correspondentes. Apesar da integridade dos crânios que compóem as três amostras, 20,42\% (17,89\% na parcela masculina e $23,78 \%$ na parcela feminina) de valores ausentes foram substituídos na série Lagoa Santa e 8,40\% (8,95\% na parcela masculina e 7,87\% na parcela feminina) na série Sambaqui. Para tanto, empregamos regressão múltipla aplicada às médias gerais (juntando-se as três séries). A estratégia de juntar as três séries foi adotada tendo em vista que o emprego das médias de cada grupo poderia aumentar artificialmente a variabilidade interséries, levando a uma distinção espúria entre as mesmas. Conseqüentemente, o grau de sobreposição entre as séries expressa uma variabilidade interséries menor, porém, muito próxima à real.

As afinidades biológicas entre as três séries aqui empregadas foram investigadas, primeiramente, por Análise de Componentes Principais (ACP), tendo por base os dados de cada espécime - ver Gower (1966) e Van Vark e Schaafsma (1992) para conceitos básicos em estatística multivariada. Para expressar essas afinidades, foram elaborados gráficos bidimensionais a partir dos dois primeiros componentes principais, ou seja, dos componentes que retêm maior capacidade explanatória. Além da posição de cada indivíduo nesses gráficos, foram também geradas elipses de inclusão de 95\%.

Posteriormente à ACP, as afinidades biológicas entre as três séries foram investigadas também através de Distâncias de Mahalanobis $\left(\mathrm{D}^{2}\right)$. Quando comparada a uma Distância Euclidiana convencional, a $\mathrm{D}^{2}$ apresenta como vantagem o fato de levar em consideração o grau de correlação e, portanto, de redundância entre as variáveis originais (Mahalanobis, 1936; Bernardo, 2007). Por essa virtude, é de longe o algoritmo mais empregado na Antropologia Biológica para investigar relaçóes de 
Walter A. Neves; Danilo V. Bernardo \& Maria M. M. OKumura

parentesco evolutivo entre distintas populações. $\mathrm{Na}$ verdade, a $\mathrm{D}^{2}$ expressa dissimilaridade: quanto maior a $\mathrm{D}^{2}$, menor o grau de afinidade biológica entre as duas séries envolvidas. E vice-versa. Para facilitar a compreensão da matriz de $\mathrm{D}^{2}$, aplicou-se sobre a mesma uma Análise de "Cluster", pelo método Ward.

Em ambos os casos, os dados craniométricos foram primeiramente corrigidos quanto ao fator "tamanho". Para tanto, empregou-se a técnica propugnada por Darroch e Mosimann (1985): para cada indivíduo, o valor de cada variável foi dividido pela média geométrica de todas as variáveis apresentadas por aquele indivíduo. Dito de uma outra manei$\mathrm{ra}$, as afinidades biológicas aqui geradas baseiam-se estritamente no fator "forma". Essa é uma estratégia comumente empregada em estudos craniométricos, tendo em vista que "tamanho" pode ser altamente influenciado por fatores ambientais imediatos, como nutrição (Corrucini, 1973). Mulheres e homens foram tratados separadamente.

\section{Resultados}

As tabelas 3, 4 e 5 apresentam as características mais importantes dos componentes principais (PC) gerados para a parcela masculina. Como podem ser verificados na tabela 3 , os dois primeiros componentes principais concentram cerca de $46 \%$ da informação contida nas 20 variáveis iniciais. As correlaçôes entre as variáveis iniciais e os dois primeiros componentes gerados podem ser avaliadas na tabela 4 . As variáveis XCB, STB e XFB, que expressam largura do crânio, mostraram alta correlação positiva com o PC1. As variáveis BPL, NAR, SSR e PRR, que expressam projeção facial, também se mostraram altamente correlacionadas com o mesmo PC. As variáveis GOL, NOL e OCC, que expressam comprimento do crânio, mostraram alta correlação negativa com o CP2. 
Revista de Antropologia, São Paulo, USP, 2007, v. 50 No 1.

As figuras 1 e 2, construídas com base nos scores apresentados na tabela 5, mostram a dispersão bidimensional dos espécimes estudados. No caso da primeira figura, a dispersão é representada sob a forma de nuvem de pontos. Já na segunda, a dispersão é representada pelas elipses de $95 \%$ de inclusão de cada série. Levando em consideração as correlações entre as variáveis craniométricas originais e o primeiro componente gerado, pode-se dizer que, quanto mais à direita e acima no gráfico, mais a morfologia é caracterizada por neurocrânios largos e curtos, além de faces pouco projetadas. Em contrapartida, quanto mais à esquerda $\mathrm{e}$ abaixo no gráfico, mais estreitos e longos são os neurocrânios e mais projetadas as faces.

Conforme pode ser facilmente depreendido das figuras 1 e 2 , ocorre uma forte sobreposição da série Sambaqui à Peru na metade direita dos gráficos, não obstante a distância geográfica entre elas. Lagoa Santa, por seu turno, encontra-se afastada dessas duas séries tardias, ocupando o lado esquerdo das figuras. Já a dispersão dos espécimes ao longo do segundo componente principal (eixo das ordenadas) não parece contribuir muito para discriminar as três séries.

As tabelas 6, 7 e 8 apresentam as características mais importantes dos componentes principais gerados para a parcela feminina. Como pode ser verificado na tabela 6 , os dois primeiros componentes principais concentram cerca de $45 \%$ da informação contida nas 22 variáveis iniciais. As correlações entre as variáveis iniciais e os dois primeiros componentes gerados podem ser vistas na tabela 7 . As variáveis craniométricas XFB, $\mathrm{STB}, \mathrm{AUB}$ e ASB foram as que mais se expressaram positivamente correlacionadas ao primeiro componente, assim como as variáveis BPL, SSR e PRR, negativamente. Quanto ao segundo componente principal, as variáveis PAC, PAS e PAF apresentam-se alta e negativamente correlacionadas com o vetor gerado. 
Walter A. Neves; Danilo V. Bernardo \& Maria M. M. Okumura

As figuras 3 e 4, elaboradas com base nos scores apresentados na tabela 8, mostram a dispersão bidimensional dos espécimes femininos estudados. No caso da primeira figura, a dispersão é representada sob a forma de nuvem de pontos. Já na segunda, a dispersão é representada pelas elipses de 95\% de inclusão de cada série. Levando em consideração as correlações entre as variáveis craniométricas originais e o primeiro componente gerado, pode-se dizer que, quanto mais à esquerda e abaixo no gráfico, isto é, quanto menor os valores para $\mathrm{CP} 1$ e CP2, mais a morfologia craniana é caracterizada por crânios estreitos, longos e com faces projetadas. Por outro lado, valores positivos nas abscissas e nas ordenadas indicam morfologia predominantemente caracterizada por crânios largos, curtos e de face pouco projetada.

Conforme pode ser facilmente depreendido das figuras 3 e 4 , ocorre novamente uma forte sobreposição da série Sambaqui à Peru na metade direita dos gráficos, ao passo que Lagoa Santa encontra-se afastada dessas duas séries mais recentes, ocupando o lado esquerdo delas. Diferentemente do que ocorreu com a parcela masculina, o segundo componente distingue razoavelmente bem Peru de Sambaqui, com a primeira série ocupando predominantemente a metade inferior do gráfico e a segunda, a metade superior do mesmo.

As Distâncias de Mahalanobis $\left(\mathrm{D}^{2}\right)$ calculadas para a parcela masculina são fornecidas numericamente na tabela 9 e visualmente na figura 5. Conforme pode ser observado, o valor da $\mathrm{D}^{2}$ entre Lagoa Santa versus Peru e/ou Sambaqui é muito maior do que o da obtida entre Peru e Sambaqui. O dendrograma obtido com a Análise de "Cluster" confirma o quadro: enquanto Peru e Sambaqui se separam a uma distância de amálgama de apenas aproximadamente 7, Lagoa Santa se separa de ambas a uma distância de amálgama de aproximadamente 25 .

As Distâncias de Mahalanobis calculadas para a parcela feminina são fornecidas numericamente na tabela 10 e visualmente na figura 6 . 
Novamente, o valor da $\mathrm{D}^{2}$ entre Lagoa Santa versus Peru e/ou Sambaqui é muito maior do que o da obtida entre Peru e Sambaqui. O dendrograma obtido com a Análise de "Cluster" aponta para a mesma direção: enquanto Peru e Sambaqui se separam a uma distância de amálgama de aproximadamente 21, Lagoa Santa se separa de ambas a uma distância de amálgama de aproximadamente 42.

Em síntese, todos os resultados obtidos indicam, claramente, que Peru e Sambaqui, duas amostras tardias, ainda que muito afastadas geograficamente, repartem uma mesma identidade morfológica, ao passo que Lagoa Santa, de antiguidade paleoíndia, apresenta identidade própria e distinta, apesar de sua maior proximidade geográfica e cronológica com Sambaqui.

\section{Discussão e conclusões}

Sinteticamente, podemos dizer que as evidências obtidas neste trabalho dão suporte inquestionável à idéia de que duas morfologias muito distintas sucederam-se no continente americano. As topologias multivariadas geradas comportam-se de acordo com o esperado: enquanto as duas amostras tardias guardam grande similaridade entre si, a amostra paleoíndia apresenta uma identidade morfocraniana própria e bastante diferenciada daquela compartilhada pelas amostras tardias.

Dois cenários podem ser sugeridos para explicar a dualidade morfológica que viemos encontrando na América do Sul ao longo do tempo. Um primeiro, advogado por um de nós (WAN) desde 1989, prega que essas morfologias já chegaram ao Novo Mundo como tais, ou seja, por meio da chegada ao continente, entre o final do Pleistoceno e o início do Holoceno, de duas populaçōes asiáticas distintas (Neves \& Hubbe, 2005). Um segundo cenário (Powell, 2005) sustenta que a morfologia 
Walter A. Neves; Danilo V. Bernardo \& Maria M. M. Okumura

paleoamericana deu origem in situ à morfologia ameríndia, por meio de processos microevolutivos locais, notadamente deriva genética. Portanto, o processo de mongolização teria ocorrido na Ásia e na América em paralelo, sendo, assim, asiáticos e ameríndios atuais um exemplo de evolução pararela-convergente.

É remota a possibilidade de que esses dois cenários possam um dia ser resolvidos com dados empíricos, tendo em vista a escassez de esqueletos humanos antigos em grande parte do território americano. Conseqüentemente, devem-se buscar critérios ad hoc, pertinentes e bem informados, para se eleger um dos dois cenários como aquele que de fato caracterizou o processo de ocupação da América. Pelo princípio da parcimônia, critério esse vastamente empregado em situações similares (Camin \& Sokal, 1965; Felsenstein, 1978), o "Modelo dos Dois Componentes Biológicos Principais" é mais verossímil que o modelo microevolutivo local, tendo em vista que requer apenas um passo evolutivo para ser explicado, enquanto o modelo microevolutivo local necessita dois, com a morfologia mongolóide-ameríndia surgindo duas vezes, na Ásia e na América, de forma independente.

Por outro lado, as informações obtidas pelo estudo do DNA de populações nativas americanas atuais vêm convergindo para um cenário de apenas uma migração ou um componente biológico, conforme já comentado na introdução (Goebel et al., 2008). Esse quadro torna-se ainda mais influente pelo fato de o DNA fóssil dos poucos esqueletos paleoíndios até o momento estudados exibir os mesmos haplogrupos presentes nas populações indígenas atuais (Kemp et al., 2007).

Mesmo assim, ainda é possível compatibilizar os dois cenários. A população com morfologia generalizada que entrou na América foi, muito provavelmente, a mesma que deu origem aos mongolóides na Ásia, que hoje predominam naquela região do planeta. Evidências ligando evolutivamente os primeiros americanos aos pré-mongolóides da Ásia já exis- 
Revista de Antropologia, São Paulo, USP, 2007, v. 50 No 1.

tem na literatura (Neves \& Pucciarelli, 1998; Kamminga \& Wright, 1988; Wright, 1995). Tudo indica que o processo de mongolização ocorreu apenas no início do Holoceno (Lahr, 1995). Antes, a Ásia era habitada por grupos não mongolóides, de morfologia generalizada. Tanto os crânios da caverna superior de Zhoukoudian quanto o crânio de Liugiang, da China, datados entre 50 e 11 mil anos atrás, confirmam esse quadro.

Com base nessas informaçōes, sugerimos que, enquanto os poucos haplogrupos já estudados mantiveram-se os mesmos durante o processo de mongolização, o mesmo não ocorreu com a morfologia craniana. $\mathrm{O}$ ambiente extremamente frio que sempre caracterizou o nordeste da Ásia parece ter selecionado uma nova morfologia craniana, sem, contudo, ter afetado as linhagens de DNA evolutivamente neutras até o momento estudadas. Vale ressaltar que nenhum dos locos estudados até agora pelos biólogos moleculares está relacionado a genes que participam da determinação da morfologia craniana - para uma revisão, ver Goebel et al. (2008).

Em outras palavras, não há nenhuma razão para se supor que marcadores moleculares e morfologia craniana evoluem ao mesmo tempo e na mesma direção, já que se trata de duas entidades evolutivas completamente distintas. Trabalhos recentes vêm questionando se linhagens de DNA e morfologia craniana são de fato entidades completamente diferentes em termos evolutivos. A maioria das informações já obtidas sobre o assunto parece apontar para o fato de que ambos os marcadores evoluem, majoritariamente, por processos estocásticos e não seletivos. O Fst de ambas as categorias gira entre 0.10 e 0.15 (Relethford, 1994, 2002), muito baixos para que forças seletivas tenham desempenhado um papel importante na geração da diversidade desses marcadores.

Mas o quadro acima se configura apenas e tão-somente quando a morfologia do crânio como um todo é levada em consideração (Roseman \& Weaver, 2004). Quando regiōes anatômicas cranianas específicas são investigadas, é inegável que pelo menos parte da variabili- 
Walter A. Neves; Danilo V. Bernardo \& Maria M. M. Okumura

dade morfológica foi fixada por seleção natural - ver Guglielmo-Matessi et al. (1979) para um exemplo.

A morfologia craniana como um todo também pode ser alterada por seleção, desde que em ambientes extremos (Roseman, 2004; Roseman \& Weaver, 2004). A gênese da morfologia mongolóide no nordeste da Ásia certamente envolveu forças seletivas, dado o extremo frio ao qual foram submetidos os pré-mongolóides que ali chegaram por volta de 40 mil anos (Lahr, 1995).

Em suma, pelo menos no tocante à ocupação inicial do Novo Mundo, é inegável que morfologia craniana e linhagens moleculares podem ter atendido a ditames evolutivos distintos, seleção natural e deriva genética, respectivamente.

\section{Nota}

1 Os autores gostariam de agradecer os curadores que facilitaram o acesso aos esqueletos de Lagoa Santa bem como suas instituiçôes: Kim-Aaris-Sørensen (Museu de Zoologia - Universidade de Copenhagen, Copenhagen), Chris Stringer (Museu de História Natural, Londres), Ricardo Ventura Santos e Hilton Pereira da Silva (Museu Nacional, Rio de Janeiro), André Prous e Cláudia Cardoso (Museu de História Natural - UFMG, Belo Horizonte) e Cybelle Ipanema (Instituto Histórico e Geográfico, Rio de Janeiro). Estes agradecimentos são extensíveis a Humberto Luiz Sobierajski, diretor do Museu do Homem do Sambaqui Padre João Alfredo Rohr (Florianópolis), onde estão alojados os esqueletos de Tapera e Base Aérea. Durante a pesquisa, os autores receberam financiamento da Fundação de Amparo à Pesquisa do Estado de São Paulo por meio de Projeto Temático (Processo Fapesp 04/01321-6 a WAN), de bolsa de mestrado (Processo Fapesp 05/52273-4 a DVB) e de bolsa de doutorado (Processo Fapesp 02/13441-0 a MMMO). WAN também recebeu apoio do CNPq durante a preparação do manuscrito por meio de bolsa de Produtividade em Pesquisa (Pesquisador 1A, Processo CNPq 305918/85-0). Este artigo é dedicado a Crodowaldo Pavan, por sua existência. 
Revista de Antropologia, São Paulo, USP, 2007, v. 50 № 1.

Tabela 1 - Composição e caracterização das séries utilizadas

\begin{tabular}{|c|c|c|c|c|c|c|}
\hline Série & Procedência & Masc. & $\begin{array}{l}\mathrm{N} \\
\text { Fem. }\end{array}$ & 6 & Período & Publicação \\
\hline Lagoa Santa & $* 1$ & 19 & 13 & 32 & $\begin{array}{c}\text { Paleoíndio } \\
\text { (entre } 11 \text { e } \\
8 \text { mil anos A.P. }{ }^{* 3} \text { ) }\end{array}$ & $\begin{array}{c}\text { Neves \& } \\
\text { Hubbe (2005) }\end{array}$ \\
\hline Sambaqui & Tapera & 28 & 29 & 57 & $\begin{array}{l}\text { Arcaico } \\
\text { (cerca de }\end{array}$ & $\begin{array}{c}\text { Okumura } \\
\text { (2007) }\end{array}$ \\
\hline & Base Aérea & 13 & 12 & 25 & mil anos A.P.) & \\
\hline Peru & $* 2$ & 55 & 55 & 110 & $\begin{array}{c}\text { Agrocerâmico } \\
\text { intensivo } \\
\text { (últimos séculos antes } \\
\text { da conquista européia) }\end{array}$ & $\begin{array}{l}\text { Howells } \\
(1973)\end{array}$ \\
\hline \multicolumn{2}{|c|}{ Total } & 115 & 109 & 224 & & \\
\hline
\end{tabular}

${ }^{* 1}$ Espécimes oriundos de diversos sítios da região de Lagoa Santa.

*2 Espécimes oriundos da região da Província de Yauyos, Peru (ver Howells, 1973).

${ }^{* 3}$ A.P.: Antes do Presente. 
Walter A. Neves; Danilo V. Bernardo \& Maria M. M. Okumura

Tabela 2 - Variáveis craniométricas utilizadas, tomadas de acordo com o protocolo estabelecido por Howells $(1973,1989)$

Abreviatura
GOL
NOL
BNL
XCB**
XFB
STB
AUB
ASB
BPL
JUB***
ZMB
FMB
EKB
DKB**
FRC
FRS***
FRF***
PAC
PAS***
PAF***
OCC
NAR**
SSR
PRR
LAR

\section{Nomenclatura*}

Glabello-Occipital Length

Nasio-Occipital Length

Basion-Nasion Length

Maximum Cranial Breadth

Maximum Frontal Breadth

Bistephanic Breadth

Biauricular Breadth

Biasterionic Breadth

Basion-Prostion Length

Bijugal Breadth

Bimaxillary Breadth

Bifrontal Breadth

Biorbital Breadth

Interorbital Breadth

Nasion-Bregma Chord

Nasion-Bregma Subtense

Nasion-Subtense Fraction

Bregma-Lambda Chord

Bregma-Lambda Subtense

Bregma-Subtense Fraction

Lambda-Opistion Chord

Nasion Radius

Subspinale Radius

Prosthion Radius

Lambda Radius

* Foi mantida a nomenclatura original, em inglês, por se tratar da norma universalmente adotada.

** Medidas presentes apenas nas análises da parcela masculina.

*** Medidas presentes apenas nas análises da parcela feminina. 
Revista de Antropologia, São Paulo, USP, 2007, v. 50 No 1.

Tabela 3 - Autovalores da matriz de co-variância e porcentagens de variância explicada por cada Componente Principal (parcela masculina)

$\begin{array}{ccccc}\begin{array}{c}\text { Componente } \\ \text { Principal }\end{array} & \text { Autovalor } & \text { \% Total } & \begin{array}{c}\text { Autovalor } \\ \text { Cumulativo }\end{array} \\ 1 & 0,009767 & 31,17544 & 0,009767 & 31,1754 \\ 2 & 0,004772 & 15,23149 & 0,014539 & 46,4069 \\ 3 & 0,004186 & 13,35994 & 0,018725 & 59,7669 \\ 4 & 0,002364 & 7,54453 & 0,021089 & 67,3114 \\ 5 & 0,002065 & 6,59205 & 0,023154 & 73,9034 \\ 6 & 0,001545 & 4,93024 & 0,024699 & 78,8337 \\ 7 & 0,001278 & 4,08009 & 0,025977 & 82,9138 \\ 8 & 0,001035 & 3,30250 & 0,027011 & 86,2163 \\ 9 & 0,000811 & 2,58787 & 0,027822 & 88,8041 \\ 10 & 0,000727 & 2,32109 & 0,028549 & 91,1252 \\ 11 & 0,000637 & 2,03182 & 0,029186 & 93,1571 \\ 12 & 0,000493 & 1,57423 & 0,029679 & 94,7313 \\ 13 & 0,000421 & 1,34490 & 0,030101 & 96,0762 \\ 14 & 0,000376 & 1,19951 & 0,030476 & 97,2757 \\ 15 & 0,000353 & 1,12816 & 0,030830 & 98,4039 \\ 16 & 0,000189 & 0,60420 & 0,031019 & 99,0081 \\ 17 & 0,000141 & 0,45060 & 0,031160 & 99,4587 \\ 18 & 0,000106 & 0,33777 & 0,031266 & 99,7964 \\ 19 & 0,000062 & 0,19853 & 0,031328 & 99,9950 \\ 20 & 0,000002 & 0,00505 & 0,031330 & 100,0000\end{array}$


Walter A. Neves; Danilo V. Bernardo \& Maria M. M. Okumura

Tabela 4 - Correlação entre os dois primeiros Componentes Principais e as variáveis originais utilizadas (parcela masculina)

$\begin{array}{ccc}\text { Variável } & \begin{array}{c}\text { Componente } \\ \text { Principal 1 }\end{array} & \begin{array}{c}\text { Componente } \\ \text { Principal 2 }\end{array} \\ \text { GOL } & -0,215895 & -\mathbf{0 , 5 6 9 8 9 6} \\ \text { NOL } & -0,062778 & -\mathbf{0 , 6 0 3 6 7 1} \\ \text { BNL } & -0,557368 & 0,068934 \\ \text { XCB } & \mathbf{0 , 8 2 4 2 9 1} & 0,350936 \\ \text { XFB } & \mathbf{0 , 8 0 9 8 0 3} & 0,261041 \\ \text { STB } & \mathbf{0 , 6 2 7 3 2 0} & 0,156467 \\ \text { AUB } & 0,447708 & 0,537621 \\ \text { ASB } & 0,365825 & 0,062730 \\ \text { BPL } & -\mathbf{0 , 6 1 0 8 6 5} & 0,185222 \\ \text { ZMB } & -0,121022 & 0,048304 \\ \text { FMB } & -0,249326 & 0,215206 \\ \text { EKB } & -0,098788 & 0,233144 \\ \text { DKB } & -0,520557 & 0,096597 \\ \text { FRC } & 0,368145 & -0,013410 \\ \text { PAC } & -0,134587 & 0,159482 \\ \text { OCC } & 0,372843 & -\mathbf{0 , 8 0 8 8 6 4} \\ \text { NAR } & -\mathbf{0 , 7 1 6 8 3 8} & -0,074489 \\ \text { SSR } & -\mathbf{0 , 7 4 8 8 5 3} & 0,005519 \\ \text { PRR } & -\mathbf{0 , 6 7 2 3 2 9} & 0,087783 \\ \text { LAR } & 0,694129 & -0,546145\end{array}$


Revista de Antropologia, São Paulo, USP, 2007, v. 50 No 1.

Tabela 5 - Coordenadas dos dois primeiros Componentes Principais (parcela masculina)

\begin{tabular}{|c|c|c|c|c|c|}
\hline $\begin{array}{c}\text { Espécime } \\
\text { (série) }\end{array}$ & CP 1 & CP 2 & $\begin{array}{l}\text { Espécime } \\
\text { (série) }\end{array}$ & CP 1 & CP 2 \\
\hline Peru & 0,059849 & 0,050495 & Sambaqui & $-0,039885$ & $-0,049372$ \\
\hline Peru & $-0,036078$ & 0,095840 & Sambaqui & 0,061741 & 0,015877 \\
\hline Peru & 0,063484 & 0,038327 & Sambaqui & 0,014776 & 0,043262 \\
\hline Peru & 0,069854 & 0,090426 & Sambaqui & $-0,020501$ & 0,004157 \\
\hline Peru & 0,126071 & 0,008181 & Sambaqui & $-0,091525$ & $-0,013940$ \\
\hline Peru & 0,021704 & 0,011993 & Sambaqui & $-0,036623$ & 0,010072 \\
\hline Peru & 0,114699 & 0,022016 & Sambaqui & $-0,070998$ & 0,086105 \\
\hline Peru & $-0,075297$ & $-0,102051$ & Sambaqui & 0,020500 & 0,130045 \\
\hline Peru & $-0,016671$ & 0,029380 & Sambaqui & 0,017071 & 0,087151 \\
\hline Peru & $-0,001264$ & 0,040689 & Sambaqui & $-0,033106$ & $-0,057873$ \\
\hline Peru & 0,085813 & 0,001310 & Sambaqui & 0,017948 & 0,074303 \\
\hline Peru & 0,085014 & 0,004259 & Sambaqui & 0,222083 & $-0,072943$ \\
\hline Peru & $-0,055580$ & $-0,092063$ & Sambaqui & $-0,010981$ & 0,138344 \\
\hline Peru & 0,105394 & 0,082164 & Sambaqui & $-0,030594$ & $-0,016537$ \\
\hline Peru & 0,021912 & $-0,124731$ & Sambaqui & 0,006254 & 0,095571 \\
\hline Peru & 0,067386 & $-0,073830$ & Sambaqui & $-0,086010$ & $-0,066456$ \\
\hline Peru & $-0,043693$ & $-0,025833$ & Sambaqui & 0,133061 & 0,044943 \\
\hline Peru & 0,033006 & 0,078703 & Sambaqui & 0,053888 & $-0,085814$ \\
\hline Peru & 0,109359 & $-0,070412$ & Sambaqui & $-0,034954$ & 0,069829 \\
\hline Peru & $-0,012245$ & 0,077140 & Sambaqui & 0,143434 & $-0,104488$ \\
\hline Peru & 0,029539 & 0,026774 & Sambaqui & $-0,057533$ & 0,008439 \\
\hline Peru & 0,037739 & 0,089626 & Sambaqui & $-0,126268$ & 0,017991 \\
\hline Peru & 0,033490 & $-0,097201$ & Sambaqui & 0,066129 & 0,028219 \\
\hline Peru & 0,031873 & 0,102571 & Sambaqui & 0,031683 & 0,041377 \\
\hline Peru & 0,127269 & 0,046172 & Sambaqui & 0,005013 & $-0,064423$ \\
\hline Peru & 0,051070 & $-0,030506$ & Sambaqui & 0,195844 & $-0,022011$ \\
\hline Peru & 0,014590 & 0,127089 & Sambaqui & 0,095142 & $-0,014469$ \\
\hline
\end{tabular}


Walter A. Neves; Danilo V. Bernardo \& Maria M. M. Okumura

$\begin{array}{lcclcc}\text { Peru } & 0,097154 & 0,017500 & \text { Sambaqui } & 0,204783 & -0,007933 \\ \text { Peru } & 0,006024 & 0,068765 & \text { Sambaqui } & -0,050245 & 0,048683 \\ \text { Peru } & 0,055219 & -0,091094 & \text { Sambaqui } & 0,052738 & 0,035446 \\ \text { Peru } & 0,011250 & 0,086052 & \text { Sambaqui } & 0,143392 & 0,028192 \\ \text { Peru } & 0,082414 & 0,010355 & \text { Sambaqui } & 0,007366 & -0,040022 \\ \text { Peru } & 0,155940 & -0,093998 & \text { Sambaqui } & 0,068946 & -0,039085 \\ \text { Peru } & -0,132180 & 0,118740 & \text { Sambaqui } & 0,045308 & 0,007458 \\ \text { Peru } & 0,046973 & -0,002021 & \text { Sambaqui } & 0,011162 & 0,044408 \\ \text { Peru } & 0,066022 & -0,088387 & \text { Sambaqui } & 0,146855 & -0,170062 \\ \text { Peru } & 0,000103 & 0,089256 & \text { Sambaqui } & 0,062043 & -0,091254 \\ \text { Peru } & -0,017803 & 0,073928 & \text { Sambaqui } & -0,080349 & 0,002472 \\ \text { Peru } & -0,041838 & 0,086587 & \text { Lagoa Santa } & -0,207561 & -0,047554 \\ \text { Peru } & -0,086559 & 0,001233 & \text { Lagoa Santa } & -0,277365 & 0,002716 \\ \text { Peru } & 0,114623 & 0,066755 & \text { Lagoa Santa } & -0,111049 & -0,039929 \\ \text { Peru } & 0,098496 & 0,014736 & \text { Lagoa Santa } & -0,255957 & -0,068574 \\ \text { Peru } & 0,028703 & -0,025290 & \text { Lagoa Santa } & -0,163145 & -0,064486 \\ \text { Peru } & 0,129219 & -0,152269 & \text { Lagoa Santa } & -0,152256 & -0,034792 \\ \text { Peru } & 0,141534 & -0,053598 & \text { Lagoa Santa } & -0,129074 & 0,088315 \\ \text { Peru } & 0,096855 & 0,096596 & \text { Lagoa Santa } & -0,086451 & 0,031531 \\ \text { Peru } & -0,041854 & -0,069652 & \text { Lagoa Santa } & -0,141937 & 0,011306 \\ \text { Peru } & -0,015728 & 0,022378 & \text { Lagoa Santa } & -0,214523 & -0,009247 \\ \text { Peru } & -0,010026 & -0,049694 & \text { Lagoa Santa } & -0,170968 & 0,046679 \\ \text { Peru } & 0,044745 & 0,022878 & \text { Lagoa Santa } & -0,265703 & -0,041225 \\ \text { Peru } & -0,044817 & -0,166829 & \text { Lagoa Santa } & -0,153664 & -0,033051 \\ \text { Peru } & -0,013152 & -0,010811 & \text { Lagoa Santa } & -0,052170 & -0,178373 \\ \text { Peru } & 0,147014 & 0,063936 & \text { Lagoa Santa } & -0,135352 & 0,029500 \\ \text { Peru } & -0,053286 & -0,011276 & \text { Lagoa Santa } & -0,056465 & -0,035198 \\ \text { Peru } & -0,022380 & -0,068699 & \text { Lagoa Santa } & -0,038796 & -0,079690 \\ \text { Sambaqui } & -0,081032 & 0,066397 & \text { Lagoa Santa } & -0,079866 & -0,066832 \\ \text { Sambaqui } & -0,040877 & -0,001156 & \text { Lagoa Santa } & -0,087436 & 0,003360 \\ \text { Sambaqui } & -0,046895 & -0,087967 & & & \\ & & & & & \end{array}$


Revista de Antropologia, São Paulo, USP, 2007, v. 50 No 1.

Tabela 6 - Autovalores da matriz de co-variância e porcentagens de variância explicada por cada Componente Principal (parcela feminina)

$\begin{array}{ccccc}\begin{array}{c}\text { Componente } \\ \text { Principal }\end{array} & \text { Autovalor } & \text { \% Total } & \begin{array}{c}\text { Autovalor } \\ \text { Cumulativo }\end{array} & \text { \% Cumulativa } \\ 1 & 0,013575 & 24,93913 & 0,013575 & 24,9391 \\ 2 & 0,010750 & 19,74907 & 0,024326 & 44,6882 \\ 3 & 0,006986 & 12,83404 & 0,031312 & 57,5222 \\ 4 & 0,004446 & 8,16694 & 0,035757 & 65,6892 \\ 5 & 0,003154 & 5,79440 & 0,038911 & 71,4836 \\ 6 & 0,002666 & 4,89716 & 0,041577 & 76,3807 \\ 7 & 0,002271 & 4,17232 & 0,043848 & 80,5531 \\ 8 & 0,001900 & 3,48994 & 0,045748 & 84,0430 \\ 9 & 0,001633 & 2,99919 & 0,047381 & 87,0422 \\ 10 & 0,001489 & 2,73585 & 0,048870 & 89,7780 \\ 11 & 0,001201 & 2,20596 & 0,050071 & 91,9840 \\ 12 & 0,001046 & 1,92229 & 0,051117 & 93,9063 \\ 13 & 0,000688 & 1,26456 & 0,051805 & 95,1708 \\ 14 & 0,000582 & 1,06850 & 0,052387 & 96,2393 \\ 15 & 0,000538 & 0,98860 & 0,052925 & 97,2279 \\ 16 & 0,000465 & 0,85381 & 0,053390 & 98,0818 \\ 17 & 0,000326 & 0,59831 & 0,053716 & 98,6801 \\ 18 & 0,000262 & 0,48061 & 0,053977 & 99,1607 \\ 19 & 0,000251 & 0,46098 & 0,054228 & 99,6217 \\ 20 & 0,000147 & 0,27041 & 0,054375 & 99,8921 \\ 21 & 0,000054 & 0,09862 & 0,054429 & 99,9907 \\ 22 & 0,000005 & 0,00932 & 0,054434 & 100,0000\end{array}$


Walter A. Neves; Danilo V. Bernardo \& Maria M. M. Okumura

Tabela 7 - Correlação entre os dois primeiros Componentes Principais e as variáveis originais utilizadas (parcela feminina)

$\begin{array}{ccc}\text { Fator } 1 & \text { Fator } 2 & \\ & & \\ \text { GOL } & 0,057004 & 0,402914 \\ \text { NOL } & 0,180978 & 0,515102 \\ \text { BNL } & -0,363840 & 0,285194 \\ \text { XFB } & \mathbf{0 , 8 1 0 3 1 6} & -0,203965 \\ \text { STB } & \mathbf{0 , 7 4 1 6 0 3} & -0,340959 \\ \text { AUB } & \mathbf{0 , 6 6 6 3 5 1} & 0,129141 \\ \text { ASB } & \mathbf{0 , 6 3 5 2 6 7} & 0,114502 \\ \text { BPL } & -\mathbf{0 , 7 1 1 4 5 8} & 0,346267 \\ \text { JUB } & 0,460490 & 0,173398 \\ \text { ZMB } & -0,302252 & 0,342879 \\ \text { FMB } & -0,224015 & 0,374977 \\ \text { EKB } & -0,362601 & 0,431376 \\ \text { FRC } & 0,262685 & 0,213056 \\ \text { FRS } & 0,100511 & -0,490891 \\ \text { FRF } & 0,041068 & -0,259721 \\ \text { PAC } & -0,382423 & -0,511965 \\ \text { PAS } & -0,218343 & -0,564991 \\ \text { PAF } & -0,316920 & -0,585610 \\ \text { OCC } & 0,302229 & 0,729912 \\ \text { SSR } & -\mathbf{0 , 6 6 9 2 9 3} & 0,473405 \\ \text { PRR } & -\mathbf{0 , 6 5 4 8 3 4} & 0,465103 \\ \text { LAR } & 0,387417 & 0,711115\end{array}$


Revista de Antropologia, São Paulo, USP, 2007, v. 50 No 1.

Tabela 8 - Coordenadas dos dois primeiros Componentes Principais (parcela feminina)

$\begin{array}{cccccc}\begin{array}{c}\text { Espécime } \\ \text { (série })\end{array} & \text { CP } 1 & \text { CP } 2 & \text { Espécime } & \text { CP } 1 & \text { CP } 2 \\ \text { Peru } & -0,000901 & 0,040473 & \text { Peru } & 0,061398 & 0,010847 \\ \text { Peru } & -0,033580 & 0,027182 & \text { Sambaqui } & -0,058290 & 0,049794 \\ \text { Peru } & 0,050920 & -0,111990 & \text { Sambaqui } & -0,047889 & 0,126297 \\ \text { Peru } & 0,016304 & -0,030677 & \text { Sambaqui } & -0,067197 & 0,122383 \\ \text { Peru } & 0,088304 & 0,149182 & \text { Sambaqui } & 0,056719 & 0,100125 \\ \text { Peru } & 0,019943 & -0,008762 & \text { Sambaqui } & 0,053301 & -0,052511 \\ \text { Peru } & 0,172630 & 0,056473 & \text { Sambaqui } & -0,119220 & 0,183711 \\ \text { Peru } & 0,170031 & -0,043635 & \text { Sambaqui } & -0,157792 & 0,003485 \\ \text { Peru } & 0,013320 & -0,097812 & \text { Sambaqui } & -0,075085 & -0,002164 \\ \text { Peru } & 0,122370 & -0,007787 & \text { Sambaqui } & -0,141562 & 0,120882 \\ \text { Peru } & 0,107921 & -0,135069 & \text { Sambaqui } & 0,017231 & 0,037832 \\ \text { Peru } & -0,057835 & -0,050767 & \text { Sambaqui } & -0,054198 & -0,045302 \\ \text { Peru } & 0,123958 & -0,055613 & \text { Sambaqui } & -0,101826 & 0,137447 \\ \text { Peru } & 0,088041 & -0,221185 & \text { Sambaqui } & 0,057854 & -0,086285 \\ \text { Peru } & 0,030471 & 0,057920 & \text { Sambaqui } & 0,079155 & 0,179820 \\ \text { Peru } & 0,194220 & -0,180773 & \text { Sambaqui } & -0,082708 & 0,079242 \\ \text { Peru } & 0,066455 & -0,073056 & \text { Sambaqui } & -0,005194 & 0,038257 \\ \text { Peru } & 0,034837 & -0,108048 & \text { Sambaqui } & -0,033956 & 0,088271 \\ \text { Peru } & 0,233246 & 0,050191 & \text { Sambaqui } & 0,011428 & 0,009232 \\ \text { Peru } & 0,044895 & -0,078439 & \text { Sambaqui } & 0,049162 & -0,024872 \\ \text { Peru } & -0,011040 & -0,140613 & \text { Sambaqui } & -0,030497 & 0,078303 \\ \text { Peru } & 0,115735 & 0,005056 & \text { Sambaqui } & -0,164412 & 0,200600 \\ \text { Peru } & 0,036146 & 0,129158 & \text { Sambaqui } & 0,186473 & 0,177596 \\ \text { Peru } & 0,086829 & -0,004385 & \text { Sambaqui } & 0,006991 & 0,040164\end{array}$


Walter A. Neves; Danilo V. Bernardo \& Maria M. M. Okumura

\begin{tabular}{|c|c|c|c|c|c|}
\hline Peru & 0,211539 & 0,155377 & Sambaqui & $-0,131136$ & 0,002563 \\
\hline Peru & 0,046941 & $-0,092895$ & Sambaqui & $-0,032532$ & $-0,045946$ \\
\hline Peru & $-0,036314$ & $-0,014384$ & Sambaqui & $-0,117743$ & 0,079157 \\
\hline Peru & 0,190863 & 0,088665 & Sambaqui & 0,055590 & 0,117948 \\
\hline Peru & $-0,002938$ & $-0,032746$ & Sambaqui & $-0,055543$ & 0,077558 \\
\hline Peru & 0,074934 & 0,001480 & Sambaqui & $-0,045204$ & 0,158679 \\
\hline Peru & 0,100222 & 0,138561 & Sambaqui & $-0,070934$ & 0,099261 \\
\hline Peru & $-0,052258$ & $-0,113234$ & Sambaqui & 0,004472 & 0,071044 \\
\hline Peru & 0,215461 & $-0,141434$ & Sambaqui & $-0,075722$ & 0,046267 \\
\hline Peru & 0,041381 & $-0,099784$ & Sambaqui & $-0,101996$ & 0,118459 \\
\hline Peru & 0,068558 & $-0,192955$ & Sambaqui & $-0,026827$ & 0,011684 \\
\hline Peru & $-0,096014$ & $-0,012346$ & Sambaqui & $-0,032324$ & 0,010725 \\
\hline Peru & 0,063516 & 0,044124 & Sambaqui & $-0,106639$ & 0,087511 \\
\hline Peru & 0,107668 & $-0,138474$ & Sambaqui & 0,036793 & $-0,015433$ \\
\hline Peru & 0,116855 & 0,029187 & Sambaqui & $-0,079907$ & 0,125976 \\
\hline Peru & 0,091848 & $-0,192193$ & Sambaqui & 0,001253 & $-0,028912$ \\
\hline Peru & 0,076624 & $-0,130633$ & Sambaqui & 0,013515 & $-0,004887$ \\
\hline Peru & $-0,057015$ & $-0,171690$ & Sambaqui & $-0,059939$ & 0,170242 \\
\hline Peru & 0,047788 & $-0,121399$ & Lagoa Santa & $-0,083112$ & $-0,211737$ \\
\hline Peru & $-0,020831$ & $-0,061322$ & Lagoa Santa & $-0,360383$ & $-0,134446$ \\
\hline Peru & $-0,113882$ & $-0,018811$ & Lagoa Santa & $-0,098191$ & 0,103756 \\
\hline Peru & 0,160336 & 0,078004 & Lagoa Santa & $-0,149380$ & $-0,103895$ \\
\hline Peru & 0,114422 & $-0,128762$ & Lagoa Santa & $-0,004311$ & $-0,151907$ \\
\hline Peru & 0,193635 & $-0,113230$ & Lagoa Santa & $-0,180022$ & $-0,075720$ \\
\hline Peru & 0,033505 & 0,113948 & Lagoa Santa & $-0,259786$ & $-0,042644$ \\
\hline Peru & 0,141499 & 0,143182 & Lagoa Santa & $-0,201050$ & $-0,074181$ \\
\hline Peru & 0,029099 & 0,036255 & Lagoa Santa & $-0,301960$ & $-0,004579$ \\
\hline Peru & 0,149131 & 0,132305 & Lagoa Santa & $-0,190637$ & $-0,026091$ \\
\hline Peru & 0,088363 & $-0,163195$ & Lagoa Santa & $-0,129095$ & $-0,026076$ \\
\hline Peru & 0,136885 & 0,132638 & Lagoa Santa & $-0,212729$ & $-0,102661$ \\
\hline
\end{tabular}


Revista de Antropologia, São Paulo, USP, 2007, v. 50 No 1.

Tabela 9 - Matriz de Distância de Mahalanobis (parcela masculina)

$\begin{array}{cccc} & \text { Peru } & \text { Sambaqui } & \text { Lagoa Santa } \\ \text { Peru } & 0,00000 & 7,40096 & 18,71121 \\ \text { Sambaqui } & & 0,00000 & 22,78347 \\ \text { Lagoa Santa } & & & 0,00000\end{array}$

Tabela 10 - Matriz de Distância de Mahalanobis (parcela feminina)

$\begin{array}{cccc} & \text { Peru } & \text { Sambaqui } & \text { Lagoa Santa } \\ \text { Peru } & 0,00000 & 21,40380 & 31,80423 \\ \text { Sambaqui } & & 0,00000 & 41,57735 \\ \text { Lagoa Santa } & & & 0,00000\end{array}$


Walter A. Neves; Danilo V. Bernardo \& Maria M. M. Okumura

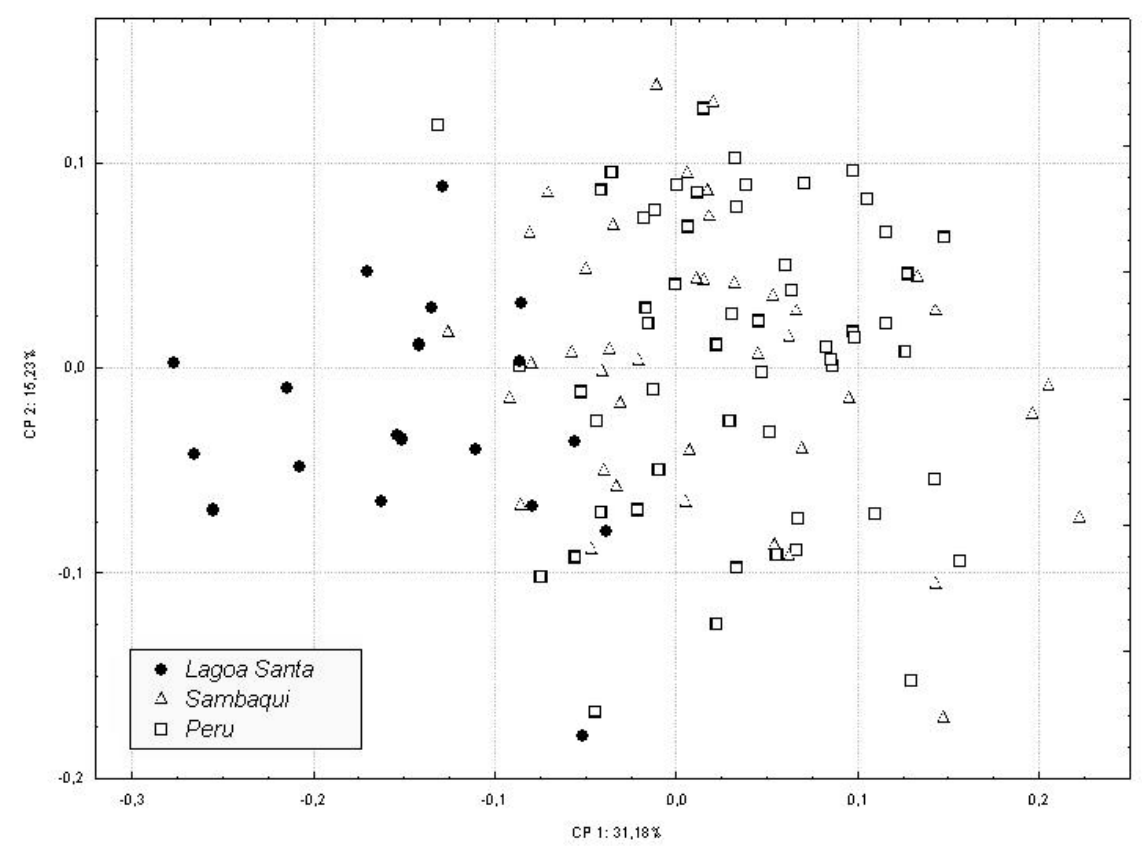

Figura 1 - Dispersão dos indivíduos analisados (parcela masculina) no morfoespaço definido pelos dois primeiros componentes principais 
Revista de Antropologia, São Paulo, USP, 2007, v. 50 No 1.

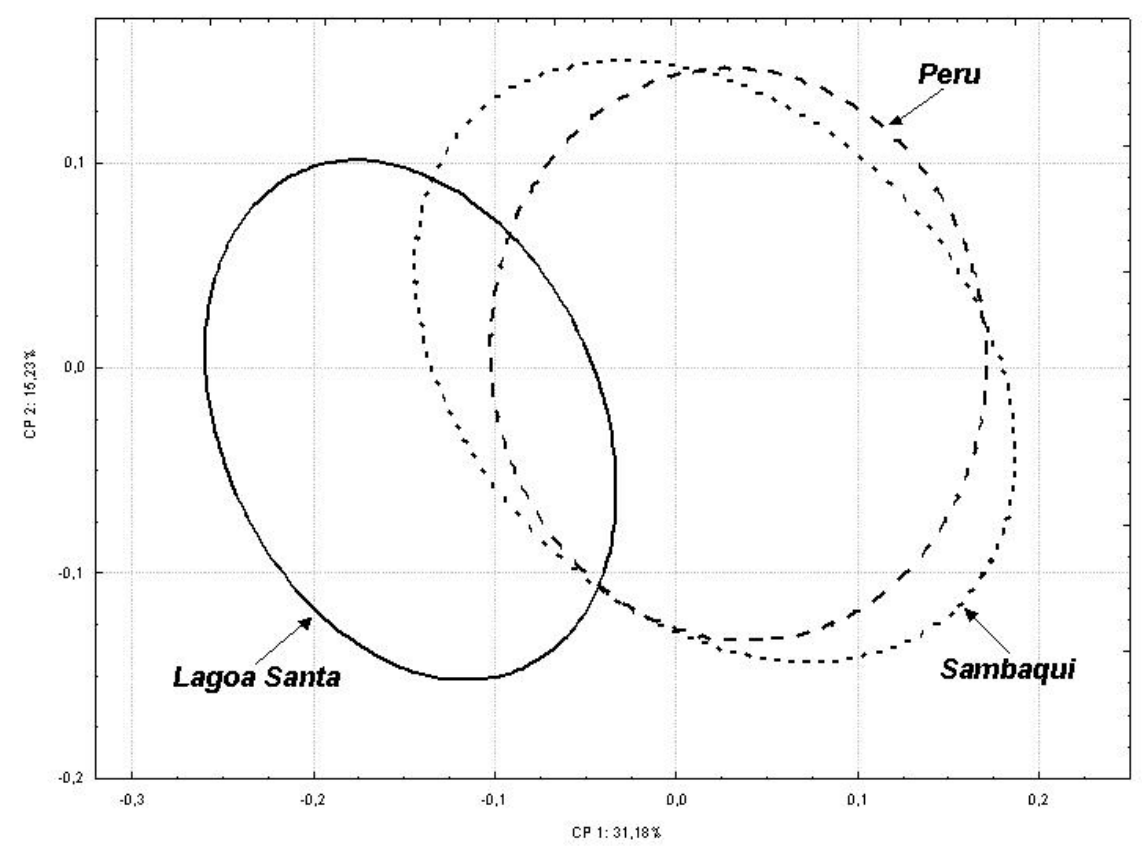

Figura 2 - Elipse de dispersão, com 95\% de confiabilidade, dos indivíduos analisados (parcela masculina) no morfoespaço definido pelos dois primeiros componentes principais 
Walter A. Neves; Danilo V. Bernardo \& Maria M. M. Okumura

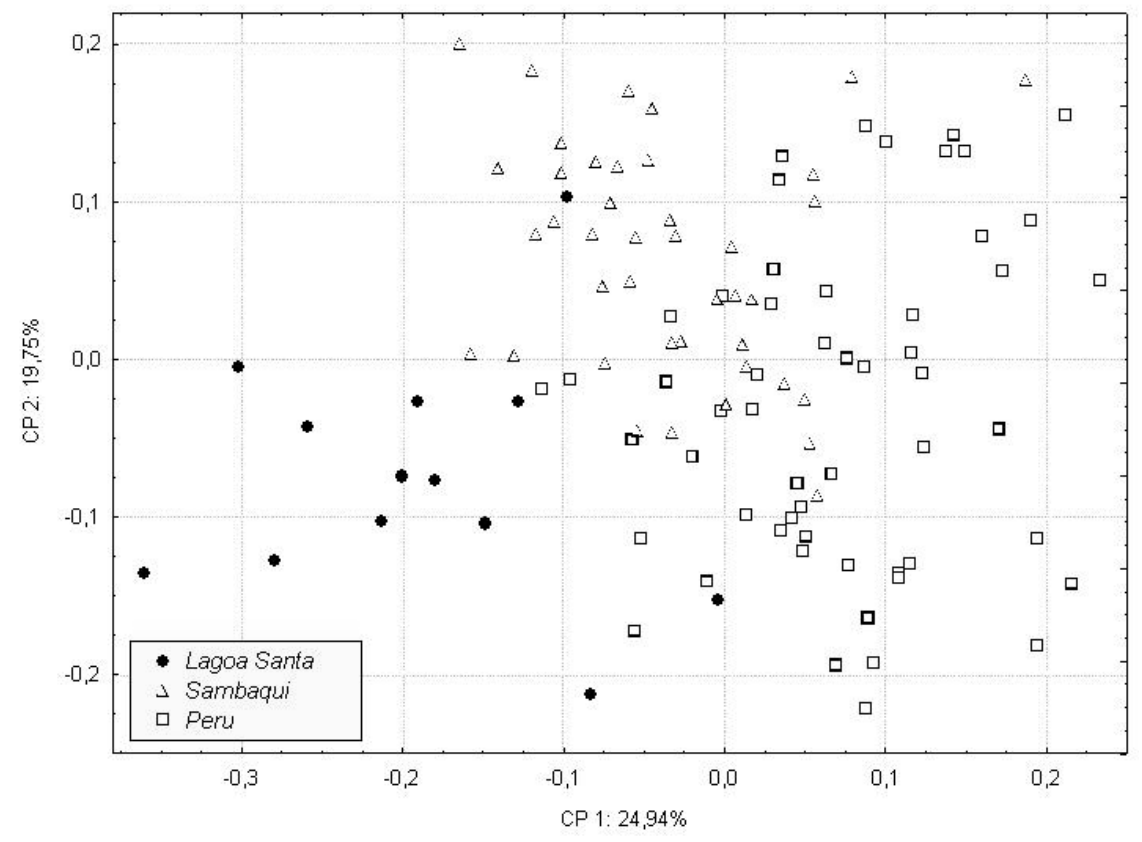

Figura 3 - Dispersão dos indivíduos analisados (parcela feminina) no morfoespaço definido pelos dois primeiros componentes principais 
Revista de Antropologia, São Paulo, USP, 2007, v. 50 No 1.

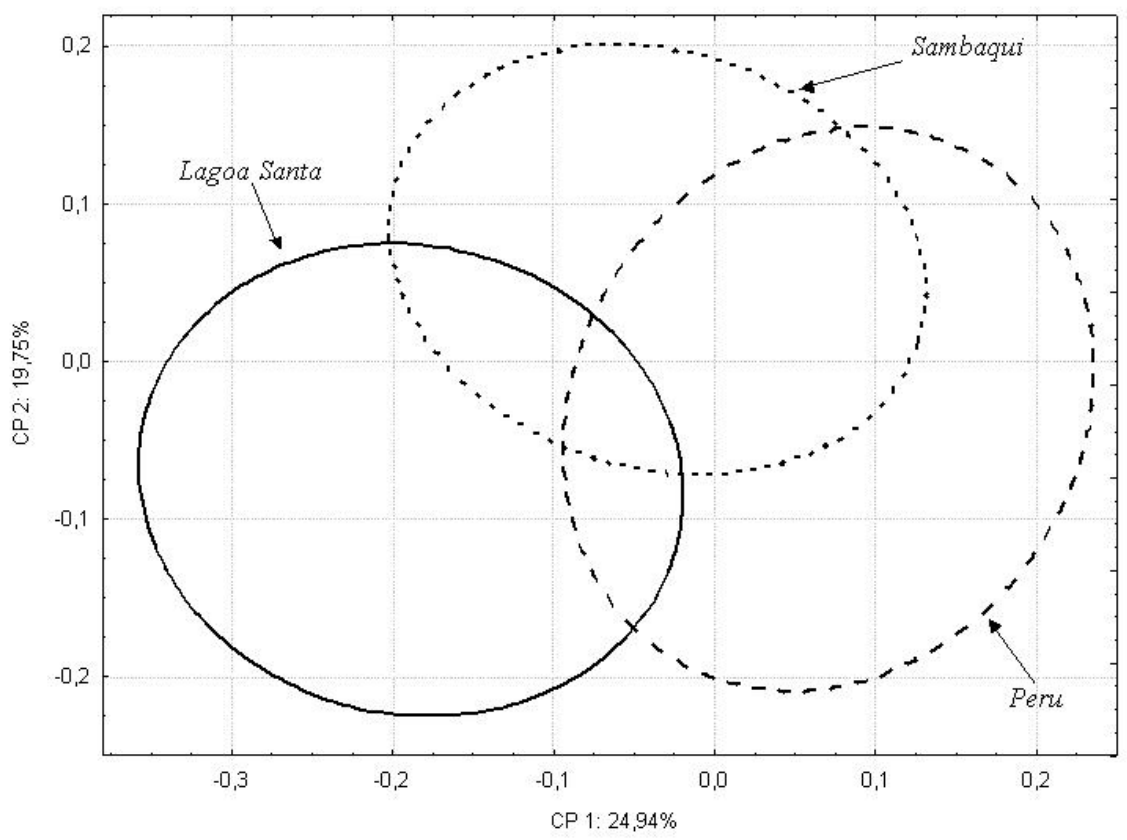

Figura 4 - Elipse de dispersão, com 95\% de confiabilidade, dos indivíduos analisados (parcela feminina) no morfoespaço definido pelos dois primeiros componentes principais. 
Walter A. Neves; Danilo V. Bernardo \& Maria M. M. Okumura

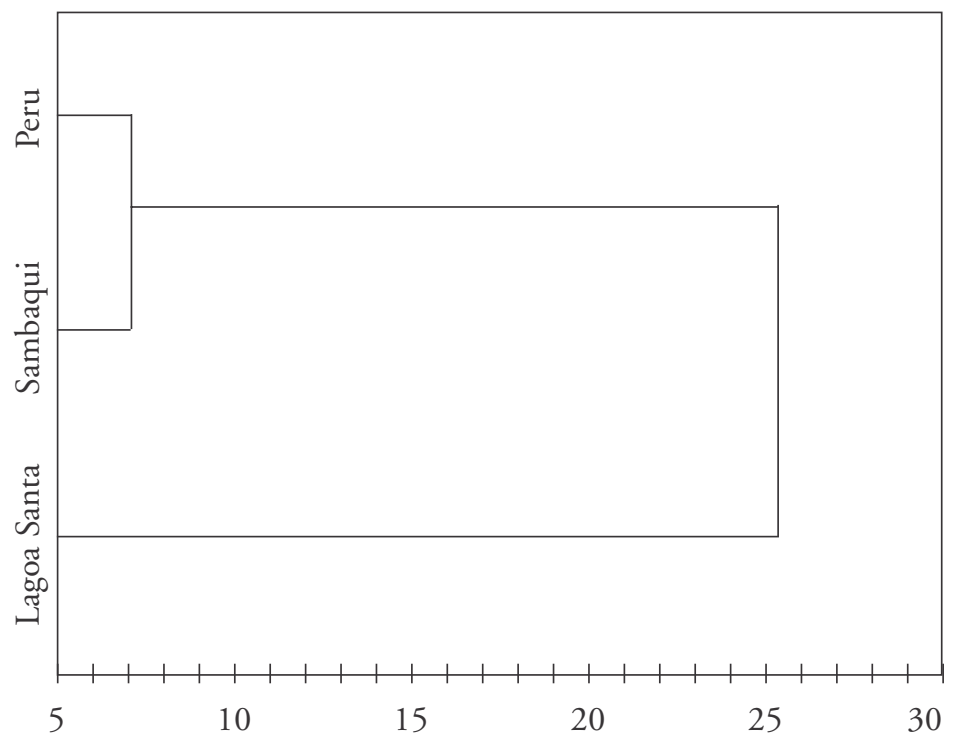

Figura 5 - Dendrograma gerado a partir da Matriz de Distância de Mahalanobis (parcela masculina) 
Revista de Antropologia, São Paulo, USP, 2007, v. 50 No 1.

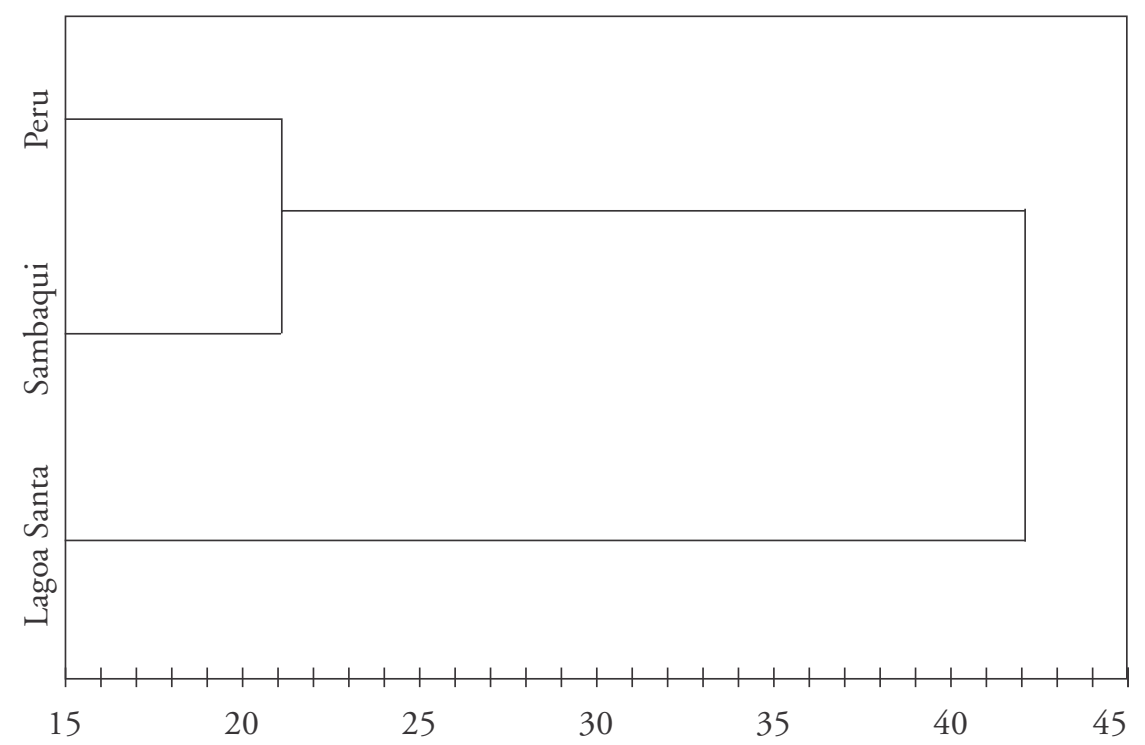

Figura 6 - Dendrograma gerado a partir da Matriz de Distância de Mahalanobis (parcela feminina) 
Walter A. Neves; Danilo V. Bernardo \& Maria M. M. Okumura

\section{Bibliografia}

BERNARDO, D. V.

2007 Afinidades morfológicas intra e extra continentais dos paleoindios de Lagoa Santa: uma nova abordagem, São Paulo, dissertação, USP, 333 pp.

CAMIN, J. H. \& SOKAL, R. R.

1965 "A Method for Deducing Branching Sequences in Phylogeny", Evolution, 19, pp. 311-26.

CORRUCINI, R. S.

1973 "Size and Shape in Similarity Coefficients Based on Metric Characters", American Journal of Physical Anthropology, 38, pp. 743-54.

DARROCH, J. N. \& MOSIMANN, J. E.

1985 "Canonical and Principal Components of Shape", Biometrika, 72, pp. 241-52.

FELSENSTEIN, J.

1978 "Cases in Which Parsimony or Compatibility Methods Will Be Positively Misleading", Syst. Zool, 27, pp. 401-10.

GOEBEL, T., WATERS, M. R. \& O'ROURKE, D. H.

2008 "The Late Pleistocene Dispersal of Modern Humans in the Americas", Science, 319 , pp. $1.497-502$.

GOWER, J. C.

1966 "Some Distance Properties of Latent Roots and Vector Methods Used in Multivariate Analysis", Biometrika, 53, pp. 325-38.

GREENBERG, J. H., TURNER II, C. G. \& ZEGURA, S. L.

1986 "The Settlement of the Americas: a Comparison of Linguistic, Dental and Genetic Evidence", Current Anthropology, 27, pp. 477-97.

GUGLIELMO-MATESSI, C. R., GLUCKMAN, P. \& CAVALLI-SFORZA, L. L.

1979 "Climate and the Evolution of Skull Metrics in Man", American Journal of Physical Anthropology, 50, pp. 549-64. 
Revista de Antropologia, São Paulo, USP, 2007, v. 50 no 1.

HENNING, W.

1965 "Phylogenetic Systematics", Annu. Rev. Entomol, 10, pp. 97-116.

HOWELLS, W. W.

1973 Cranial Variation in Man. A Study by Multivariate Analysis of Patterns of Difference among Recent Human Populations, Papers of Peabody Museum of Archaeology and Ethnology, Cambridge, Harvard University Press.

1989 Skull Shapes and the Map. Craniometric Analysis in the Dispersion of Modern Homo, Papers of Peabody Museum of Archaeology and Ethnology, Cambridge, Harvard University Press.

1999 Who's Who in the Skulls, Papers of Peabody Museum of Archaeology and Ethnology, Cambridge, Harvard University Press.

JANTZ, R. L. \& OWSLEY, D. W.

2001 "Variation among Early North America Crania", American Journal of Physical Anthropology, 114, pp. 146-55.

KAMMINGA, J. \& WRIGHT, R. V. S.

1988 "The Upper Cave at Zhoukoudian and the Origins of the Mongoloids", Journal of Human Evolution, 17, pp. 739-67.

KEMP, B. M., MALHI, R. S., MCDONOUGH, J., BOLNICK, D. A., ESHLEMAN, J. A., RICKARDS, O., MARTINEZ-LABARGA, C., JOHNSON, J. R., LORENZ, J. G., DIXON, E. J., FIFIELD, T. E., HEATON, T. H., WORL, R. \& SMITH, D. G.

2007 "Remains from Alaska and its Implications for the Settlement of the Americas", American Journal of Physical Anthropology, 132(4): 605-21.

LAHR, M. M

1995 "Patterns of Modern Human Diversification: Implications for Amerindian Origins”, Yearbook of Physical Anthropology, 38, pp. 163-98.

1996 The Origin of Modern Human Diversity: a Study of Cranial Diversity, Cambridge, Cambridge University Press.

MAHALANOBIS, P. C.

1936 "On the Generalized Distance in Statistics", Proceedings of the National Institute of Science of India, 12, pp. 49-55. 
Walter A. Neves; Danilo V. Bernardo \& Maria M. M. Okumura

NEVES, W. A.

1988 "Paleogenética dos grupos pré-históricos do litoral sul do Brasil (Paraná e Santa Catarina)", Pesquisas (Antropologia), 43, Instituto Anchietano de Pesquisas.

NEVES, W. A. \& HUBBE, M.

2005 "Cranial Morphology of Early Americans from Lagoa Santa, Brazil: Implications for the Settlement of the New World", Proceedings of the National Academy of Science, 102, pp. 18.309-14.

NEVES, W. A. \& PUCCIARELLI, H. M.

1989 "Extra-Continental Biological Relationships of Early South American Human Remains: a Multivariate Analysis", Ciência e Cultura, 41, pp. 566-75.

1990 "The Origin of the First Americans: an Analysis Based on the Cranial Morphology of Early South American Human Remains", American Journal of Physical Anthropology, 81, p. 274.

1991 "Morphological Affinities of the First Americans: an Exploratory Analysis Based on early South American Human Remains", Journal of Human Evolution, 21, pp. 261-73.

OKUMURA, M. M. M.

2007 Diversidade morfológica craniana, micro-evolução e ocupação pré-histórica da costa brasileira, São Paulo, tese, USP, 406 pp.

POWELL, J. F.

2005 The First Americans: Race, Evolution and Origin of Native Americans, Cambridge, Cambridge University Press.

RELETHFORD, J. H.

1994 "Craniometric Variation among Modern Human Populations", American Journal of Physical Anthropology, 95, pp. 53-62.

2002 "Apportionment of Global Human Genetic Diversity Based on Craniometrics and Skin Color", American Journal of Physical Anthropology, 118, pp. 393-98.

ROSEMAN, C. C.

2004 "Detecting Interrregionally Diversifying Natural Selection on Modern Human Cranial Form by Using Matched Molecular and Morphometric Data", Proceedings of the National Academy of Science, 35, pp. 12.824-9. 
Revista de Antropologia, São Paulo, USP, 2007, v. 50 No 1.

ROSEMAN, C. C. \& WEAVER, T. D.

2004 "Multivariate Apportionment of Global Human Craniometric Diversity", American Journal of Physical Anthropology, 125, pp. 257-63.

SCHIMITZ, P. I.

1959 "A cerâmica da ilha de Santa Catarina e a cerâmica de Base Aérea", Pesquisas, 18 , pp. 127-40.

1996 "Visão de conjunto dos sítios de Tapera, Armação do Sul, Laranjeiras I e II, Pântano do Sul e Cabeçudas - Escavações Arqueológicas do Pe. João Alfredo Rohr, S. J.”, Pesquisas (Antropologia), 53, pp. 183-90.

SCHURR, T. G.

2004 "The Peopling of the New World: Perspectives from Molecular Anthropology", Annual Rev. Anthropology, 33, pp. 551, 583.

VAN VARK, G. N. \& SCHAAFSMA, W.

1992 "Advances in the Quantitative Analysis of Skeletal Morphology", in SAUNDERS, S. R. \& KATZENBERG, M. A. (ed.), Skeletal Biology of Past Peoples: Research Methods, New York, Willey Liss Inc., pp. 225-57.

WRIGHT, R. V. S.

1995 "The Zhoukoudian Upper Cave Skull 101 and Multiregionalism", Journal of Human Evolution, 29, pp. 181-3.

ABSTRACT: Until mid 1990s the prevailing model to explain the early colonization of the Americas rested on the assumption that three different migrations were involved in the process. The first migration would have given rise to most of the modern Native Americans, and is known as "Amerind"; the second migration would have given rise only to the Na-Dene Indians of the northern pacific; while the third would have given rise to the Eskimos and Aleuts. Known as the Three Migrations Model, the model was said to rest on convergent evidences coming from dental morphology, linguistics and the gene pool of living Native Americans. By the time the model was formulated, genetic diversity of living humans was studied by means of 
Walter A. Neves; Danilo V. Bernardo \& Maria M. M. Okumura

gene products, like serum proteins, and not by means of DNA itself. From mid 1990s on, two other models to explain the origin of Native Americans started competing with the Three Migration Model. They are known today as The Two Main Biological Components Model, and The Single Migration Model. The first one rests on the analysis of the cranial morphology of extinct and extant Native Americans along time, while the second has emerged from the study of DNA polymorphisms of living populations, mainly from mitochondrial and $\mathrm{Y}$ chromosome DNA sequencing. In other words, evidence coming from cranial morphology and its variation along time sustains that two Northern Asian populations entered the continent: the first one exhibiting a more generalized cranial pattern, and a second one exhibiting a more specialized architecture. On the other hand, the distribution of DNA haplogroups in modern Native American populations is easily explained by the entrance of only one mother population from Northern Asia. In this study we present new evidence that two very distinct cranial morphologies are indeed found among extinct Native Americans along time: a more generalized cranial pattern typifying the first newcomers, known in the literature as Paleoindians ( 12 to 8 thousand years ago), and a more specialized pattern typifying latter groups, since the Archaic period $(<8$ thousand years). Although exceptions to this temporal logic have already been found, the chronology proposed seems to work in the vast majority of the American continent. The results obtained are discussed under the light of those generated by Molecular Biology of extant Native Americans.

KEY-WORDS: Three Migration Model, Two Main Biological Components Model, Native American DNA, Cranial Morphology, First Americans.

Recebido em novembro de 2007, aceito em dezembro de 2007. 